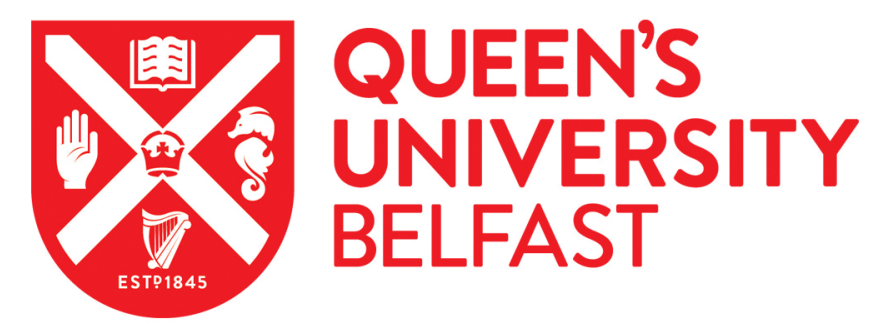

\title{
Reconciliation Programing and Discourse in Northern Ireland since the Good Friday Agreement of 1998
}

Barry, J., \& Burke , B. (2020). Reconciliation Programing and Discourse in Northern Ireland since the Good Friday Agreement of 1998. In S. Gooden (Ed.), Global Equity in Administration : Nervous Areas of Governments Routledge.

Published in:

Global Equity in Administration

Document Version:

Peer reviewed version

Queen's University Belfast - Research Portal:

Link to publication record in Queen's University Belfast Research Portal

Publisher rights

Copyright 2020 Routledge. This work is made available online in accordance with the publisher's policies. Please refer to any applicable terms of use of the publisher.

\section{General rights}

Copyright for the publications made accessible via the Queen's University Belfast Research Portal is retained by the author(s) and / or other copyright owners and it is a condition of accessing these publications that users recognise and abide by the legal requirements associated with these rights.

Take down policy

The Research Portal is Queen's institutional repository that provides access to Queen's research output. Every effort has been made to ensure that content in the Research Portal does not infringe any person's rights, or applicable UK laws. If you discover content in the Research Portal that you believe breaches copyright or violates any law, please contact openaccess@qub.ac.uk. 


\title{
Part III
}

\section{Religion \& Community}

\section{0}

\section{Reconciliation Programing and Discourse in Northern Ireland since the} Good Friday Agreement of 1998

Brendan F. Burke 0000-0002-6408-8684 and John Barry 0000-0002-6543-7698

\begin{abstract}
The history of Northern Ireland is dominated by the conflict between two factions; one consists of loyalists who favor rule from the UK, and are largely Protestant, while the others favor a unified republic of Ireland, and are largely Catholic. The Catholic republican minority has been marginalized in Northern Irish society until recently, and this political/religious difference (expressed officially as 'community background') still leads to episodic tensions and violence in the region. Since the peace accords of 1998, known as the Good Friday Agreement, several efforts focused on the Northern Ireland Civil Service (NICS) have reduced the disparity between Catholics and Protestants in the government workforce and, through a deliberative and analytic process, have grown to respond to other inequities in the offerings of all of the region's government organizations. This chapter details the center of the conflict, the 'nervous' topic of discussing political/religious difference, and the political and administrative mechanisms that have brought a modicum of hope and progress to the governance of Northern Ireland.
\end{abstract}

\section{A Nervous Area of Government in Northern Ireland}

How does a system reorient itself from centuries of enduring inequity toward a fairer society in the present day, and for future generations? This chapter assesses efforts to reconcile a cultural divide between two long-dominant identities in Northern Ireland, ostensibly linked, on the one hand, by loyalty toward rule by the UK and generally of the Protestant faith, contrasted, on the other, with those who support unity with the Irish republic, predominantly consisting of Roman Catholics. After centuries of unrest between these groups, in the form of revolution, civil war, 
and more recently a 30-year terrorist conflict, progress has been made toward ending the violent conflict and moving towards the reconciliation between its peoples, mediated by a reformed governance system. But with enduring bitterness and the legacy of the past to be overcome, Northern Ireland is not changing without some growing pains.

Gooden's (2014) introduction of 'nervous areas of government' focuses on racial dynamics and their impact on social inequity in the United States. The findings of Gooden's work are important within other identity-based differences and to other nations. But these differences and their equity impacts are nuanced when applied in other settings. First, it is important to Gooden's argument that racism and other injustice-producing differences include a very important unspoken and institutionalized nature, such that governments and organizations tend to accept inequity as a condition to be managed rather than as a problem to be resolved and transformed. The American civil rights movement advanced fairness in American society, but its legalistic focus placed the resolution of inequities into the adversarial forum of the courts and legal system in many cases, rather than into voluntary, cultural, and other extra-intuitional-cum-legal cooperative settings for the resolution of differences and their impacts. In Northern Ireland, the American civil rights movement was an inspiration for republican and Catholic protesters in the late 1960 s and early 1970 s as they attempted to redress their historical subjugation, but when neither the unionist- and Protestant-dominated Northern Ireland government nor the UK government was moved by the demonstrations (or rather the latter was motivated to act too little, too late, and in a problem exacerbating manner), the protest moved to an active, terrorist war for approximately 30 years. The need to overcome the conflict and resolve differences did prompt a set of 'peace' agreements and acts to reduce inequity; appearances were that resolution was ready for action by 1998, when the Belfast/Good Friday Agreement was signed. Second, in the 
case of race in America, differences are visible but frequently underanalyzed. In Northern Ireland, an island with very little racial diversity throughout its history, the differences on which we focus are internal; there is no racial difference between the 'two communities,' and limited ethnic difference. Religious and political differences are unclear until the participants reveal them through discussion or questioning. But this contrast between Protestant/loyalists and Catholic/republicans created "knife-edge times" in Northern Irish society at least until the end of the 12th century (Burns 2018). It is only with the softening of this tense situation that other inequities have come onto the Northern Irish political agenda. Third, statistics reveal an ongoing inequity in American public policies, based in the distribution of different benefits that are affected by government action in some cases, intransigence in others (Gooden 2014, 28-39). In Northern Ireland, some surface differences are being resolved quite quickly since 1998, but with other gaps in the policy response just under way (Brennan 2017; Long 2018). Fourth, the tone of discussion in resolving differences in the two nations is different. In the United States, the central "nervous" discussion component is a lack of acknowledgement that racism still persists; in Northern Ireland, the difficulty is the passion that arises over politics and faith once the discussion starts. It is very hard for individuals and communities in Northern Ireland to get over previous wrongdoing by one side, aimed at the other. This may undergird Northern Ireland's greatest contribution to resolution of 'nervous' areas: lessons in how to move dialogue from bitterness toward productive and shared (even if disputed) memories, grieving and loss, and then moving on to (sometimes uneasy and unstable) mutual accommodation and then power sharing as necessary steps on the road to (perhaps) reconciliation and a 'positive peace.'

This chapter moves through four sections: First, it displays the history of group difference and conflict in Northern Ireland, with the impact of governmental discrimination on communities, 
policies, and work force. Second, it highlights the innovative peace process that was brokered in 1998, and its offshoots to enhance fairness in civil service hiring and provision of community services. These were not perfect processes, but they did move Northern Ireland forward in dramatic and important ways. Third, the government's current process for deliberation on policy equity is outlined. This process is more holistic with regard to inequality in Northern Ireland, a movement beyond just the main historical division addressed in the first efforts after the Peace Accords. And finally, it discusses the relevant lessons from Northern Ireland to enhance how other states and communities can confront other areas and sources of inequity.

Commented [CM1]: AU: Is capitalization necessary here? Commented [BB2R1]: Yes, it was a formal treaty

\section{Why Faith Difference Is a Nervous Area of Government}

Ireland's history is dominated by invasions and conflicts of varying intensity to create, sustain, and protect an Irish identity. Romans, Vikings, Normans, and the British provided a consistent line of war and struggle for control of the island, until the partition of Ireland in 1922. This created an Irish Free State (in the south) in 1922-with an overwhelming Catholic Irish majority, and Northern Ireland, with a Protestant British majority. But that was the beginning of an internal conflict over external rule based on colonization by Britain, first in a civil war across the island, then concentrated within the newly created 'statelet' or province of Northern Ireland. The Norman and British invasions had populated the island in earlier centuries, and provide the roots for conflict over Celtic identity among several different subpopulations. For simplicity's sake, these are expressed as those loyal to the UK, predominantly of the Protestant faith, and those who support an independent and united Irish republic, mostly claiming the Catholic faith. This is an oversimplification of sorts, as faith does not appear to be central to dispositions in an ongoing violent and bloody battle. Rather religious affiliation should be viewed as a convenient 'badge' of political identity and aspiration for the island in whole (united) or part (continuation of 
Northern Ireland as part of the UK). The two groups are captured in governmental discussions through the shorthand expression of 'community background.'

Among other characteristics of the Irish peoples is an affinity for folklore and storytelling, through its literature, song, and visual arts. The Irish playwright Brian Friel tells of British surveyors who roamed the Irish countryside early in the 19th century, converting Irish place names from their Gaelic to English expressions ('Baile Beag' converted to 'Ballybeg,' for example) in his play, Translations. Elizabeth Bowen tells the story of The Big House, the symbolic estate home of the Protestant landlords before Irish independence. The socialist Sean O'Casey, in The Plough and the Stars, tells of the folly of violent conflict in the Easter Uprising of 1916, which prompted active revolution and did lead to Irish independence, but did not focus on class differences and socio-economic injustice. Indeed, the play itself led to violence, a riot at the Abbey Theatre in 1926 over its class-based critique of the independence movement. This line of literature highlights in different ways the suppression and subjugation of a fully Irish identity in favor of colonial overlords from the UK.

It was the 1922 treaty to end conflict between the UK and Irish republican forces (the original Irish Republican Army as it were), and the partition of Ireland, that planted the seed for ongoing conflict in Northern Ireland, erupting into the decades long armed conflict known as 'the Troubles,' which erupted in 1968-1969 and ended in 1998. The Anglo-Irish Treaty of 1922 gave Irish independence to most of the southern three provinces (Leinster, Munster, and Connacht) as long as they pledged loyalty to the Crown (constitutionally the 'Irish free state' or Saorstát Éireann as it was known, which was established as a Dominion of the British Commonwealth much like Canada or Australia). This condition would be dropped in time as the Irish state moved to full independence when Ireland's Dominion status was terminated with the passage of 
the Republic of Ireland Act 1948, which declared that the state was a republic. But one aspect of the Treaty endured and maintained a bitter divide. Most of Ulster (six of the nine counties that made up this fourth Irish province) remained with the UK, as a gerrymandered border was drawn to exclude Catholic-dominated counties of Ulster (Cavan, Monaghan, Donegal) from the newly created Northern Ireland. The simplest part of the boundary leaves these three predominantly Catholic counties to the Irish state, but smaller pockets along the border were included or excluded from Northern Ireland based on political loyalty and faith differences.

The artistic expression of loyalist/republican differences is clearest in murals, seen throughout Belfast in segregated neighborhoods. A popular and informative lesson can be gleaned from the 'Black Taxi Tour.' When one drives up the Falls Road, murals on this republican side commemorate the Easter 1916 Uprising and its republican heroes, as well as other pioneers of civil rights movements like Nelson Mandela and the freed African American slave and abolitionist Frederick Douglass. One of the most famous murals on the Falls Road side is of Bobby Sands, a member of the Irish Republican Army who was elected to the UK's Parliament on the night that he died (5 May 1981), from participation in a hunger strike in the Maze prison. The Falls Road flag is clearly the tricolor of the Republic of Ireland, on display on many businesses and homes. When crossing over to the loyalist side, the murals change dramatically, to commemorations of King William of Orange's 1690 victory to preserve Britain's place in Ireland, and prevent a Catholic, King James, from being Monarch; quotes from the early 20th century such as "Ulster will fight, and Ulster will be right"; and memorials to paramilitaries from the Ulster Defence Association or Ulster Volunteer Force, killed in conflict with the IRA or the British Army. The flag of the Shankhill neighborhood is, without question, the Union Jack. Memories are very long of the fights between groups, and this line of history is well documented 
(Barry 2019; Bew 2010; McGarry 2019). Over 3,500 people, at least 1,700 of them civilians died in the conflict between 1969 and 1998, before the peace talks of the 1990s moved forward to their eventual conclusion, under the chairpersonship of US Senator George Mitchell in 1998. The prevailing nature of life in Northern Ireland involves ongoing tension between these two 'sides.' When one takes the Black Taxi tour through West Belfast, one of the most impressive icons is the 'peace wall,' an approximately 30 foot high, dull green structure with gated access points between the Protestant/loyalist and Catholic/republican neighborhoods. Now, this wall is a symbol of peace, with colorful, spraypainted images and artistic expressions along its base; anyone can write their message of hope, remembrance, and peace on the wall's surface (including the Dalai Lama, who left his message in 2000). But historically, the wall served the function of closing off and separating violent factions of youths when the conflict grew heated. The wall, and over one hundred others like it around Northern Irish cities, is tall enough so that youths could not throw Molotov cocktails_-gasoline bombs—-from one neighborhood to the other.

But day-to-day life in Belfast was tense as well, with ongoing fear of violence and reprisal between the two sides in the conflict. The hair-trigger anxiety within this split is recorded effectively in The Milkman, Anna Burns's Man Booker Prize-winning novel about Belfast in the 1970s. The wry humor within the novel captures sad tensions that loyalist or republican residents of Belfast could become conflictual over the other 'side's' names, schools, workplaces, sports teams, church hymns, newspapers, and more. The protagonist in the novel claims that there is "the tea of allegiance (and) the tea of betrayal," with wit—but only marginally (Burns 2018). Tension between these segregated groups was constant, especially because of the higher level of direct violence that could quickly arise. This was not true everywhere in Northern Ireland; 
tensions were reduced in rural areas. But in the dense regions of the two main cities of Derry (also called Londonderry, by loyalists) and Belfast, these constraints on daily life prevailed until recently, and have not eased completely.

This conflict between political and religion-based factions steadily stunted virtually any form of progress in Northern Ireland, until the end of the 12th century. When the Good Friday Agreement was crafted and negotiated in 1998, political leadership within Northern Ireland was ready for an innovative movement toward peace; alongside of this, it was clear that some equalization of access to positions within the civil service would help to move toward equality for the disadvantaged minority within the territory - the Catholic republicans. Figure 10.1 shows the disparity over time between the overall Catholic population and the presence of Catholics in the Irish civil service, which has been corrected through some reform efforts especially since 1998. In the next section, the Peace Accord and its implementation are discussed.

<COMP: Place Figure 10.1 Here>

Promising Government Initiatives: The Good Friday Agreement, the Patten Act, and Section 75 of the Northern Ireland Act

Ever after the Anglo-Irish Accords of 1922, equity in the civil service was addressed by the Northern Ireland government, but with some indifference on both sides. The civil service was supposed to be allotted with a goal of one-third Catholics as job holders, which would match the ratio of Catholics in the overall population. Within the police force, the Royal Ulster Constabulary (RUC), only one-sixth of positions were pursued by Catholics, at the outset. Leadership within the civil service was limited to Protestants. At times, the Northern Ireland executive, under leaders like James Craig, pressed for Catholic inclusion in the civil service, but bowed easily in the face of local Protestant opposition (Patterson 2007). At other times even 
'reformist' and 'progressive' unionist leaders such as the ill-fated Terrence O’Neill betrayed a deep misunderstanding and sectarian (quasi-racist) view of Catholic nationalists as when he stated the following in 1969 as Prime Minster of Northern Ireland:

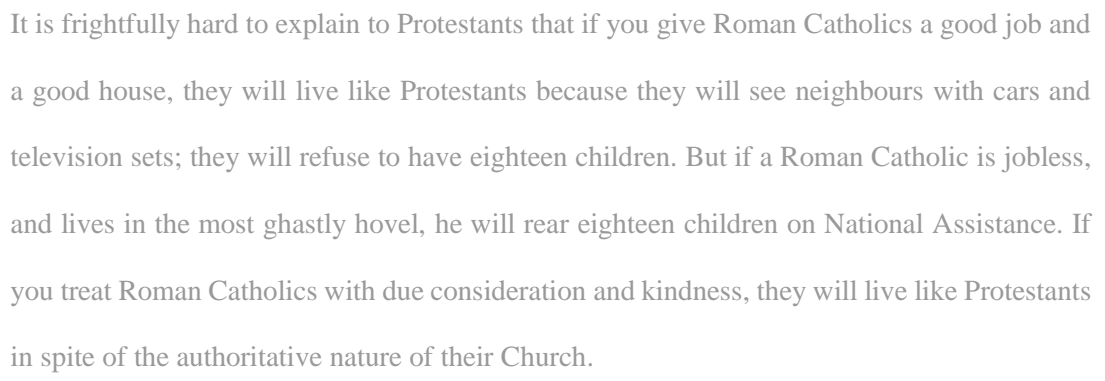

The sharing of civil service positions completely stopped when the UK government took control of Northern Ireland out of the state's hands, with rule from Westminster, in 1972, as a result of widespread gerrymandering, police brutality, and outbreak of lawlessness. Local governance and administration returned, almost three decades later, when the Good Friday Accord was put in place.

Gradual movement toward peace between loyalists and republicans proceeded throughout the 1990s. Rapprochement occurred between political parties in Northern Ireland (most notably, the Social Democratic and Labour Party or SDLP under John Hume and Sinn Fein leader Gerry Adams in the early part of the decade), as well as between executive leadership of the Republic of Ireland and the UK (Ireland's Taoiseach Bertie Ahern and the UK's Prime Minister Tony Blair, respectively). Leading the negotiation was retired US Senator George Mitchell. The theme of all discussions was reestablishment of local governance and the creation of an inclusive power-sharing executive so that there would be the return of a democratically elected Northern 
Ireland Assembly, the institution of an Irish-British Conference for those two governments, and a committee to handle cross-border issues. Two referenda helped to bring the agreement to fruition; first was a referendum within Northern Ireland on accepting the Accord (passed with $71 \%$ support), and a vote in the Republic giving up its constitutional claim to Northern Ireland (passed with 94\% support). However, while overwhelmingly supported, there were significant differences between unionists and nationalists. As Hayes and McAllister note: "Although the Agreement was formally ratified by 71 percent of voters in the referendum held on 22 May 1998, only a narrow majority of Protestants voted to support it" (Hayes and McAllister 2001: 73). The reality is that in Northern Ireland while over $90 \%$ of Catholics voted for the Agreement, only $57 \%$ of Protestants did, and the now largest party in Northern Ireland, the Democratic Unionist Party (DUP) campaigned against the Agreement.

It should be pointed out that while the Republic's government went along with this policy, it did include a provision that the people of Northern Ireland could revisit the unification of the island under the Republic's government if supported in a future referendum. Under the provisions of the Agreement the UK Secretary of State for Northern Ireland - currently Karen Bradley—has to call a vote if it appears likely there would be a majority for a united Ireland.

Implementation of the Good Friday or Belfast Agreement would follow over the next decade. One of the most important components politically was the involuntary power-sharing agreement between loyalist and republican leadership. In 2007 Ian Paisley, the leader of the Democratic Unionist Party, and Martin McGuinness, the Sinn Fein leader in Northern Ireland (and former IRA commanding officer in Derry), came together to serve as First Minister and Deputy First Minister in the capital building of Stormont, establishing a coalition to unite the two sides, based in large part on supplanting their two more moderate rivals - the SDLP and the Ulster Unionist 
Party (UUP) who had established power sharing since 1998. This was an impressive

achievement, given the vitriol that Paisley had spread in earlier days against Catholics, from the pulpit as a Free Presbyterian minister, only equaled by McGuinness's violent opposition to the partition of Ireland and the Northern Ireland statelet while he served as an IRA commander. The power-sharing agreement would last until January 2017, but fell when McGuinness resigned as Deputy First Minster and collapsed the government. The Northern Ireland Assembly or government has not met since then. But the symbolism of this alliance, while it held, was clear: Even the most extreme of rivals could work together, with the goal of establishing peace between the sides.

Since 1972, the center of the UK's rule in Northern Ireland has come with few breaks from the civil service. Three different reforms affecting the civil service were central to the implementation of the Belfast Agreement, with the goal of bridging divides within communities. In 1998, the UK Parliament passed the Fair Employment and Treatment Order for Northern Ireland, which prioritized the elimination of Catholic/Protestant disparities in the Northern Ireland Civil Service (NICS). Affirmative or 'positive' action was integrated into workforce review and development for all public authorities, and has met with broad success. The analytic arm of the NICS was able to track a steady progression during the first decade of this century toward parity between Catholics and Protestants in the civil service, in aggregate. The UK government rarely collected data on this demographic within the civil service during the first several decades of the existence of the NICS (Buckland 1979; Irish Times 2010). Some public authorities would lag in this movement. The toughest conversion to a fair and equitable civil service resides in the public safety realm; in 1999, British politician Christopher Patten was tasked with convening the Independent Commission on Policing for Northern Ireland. Their 
product was titled 'A New Beginning: Policing in Northern Ireland' (1999). The commission and report both adopted the name of its chair. Police experts from around the world served on the Patten Commission, offering the best in policing philosophy and practice in the writing of the Patten Report. Several dramatic changes emerged from the Report's recommendations, and while these were resisted by portions of either side from the earlier conflicts, most have been implemented and have proven successful. The third reform is known as Section 75 of the Northern Ireland Act of 1998; it is the mechanism by which ongoing assessment of the equity within Northern Irish policy and administration receives due consideration. The rest of this section treats the affirmative action and Patten Report reforms that created much progress by 2010. The following section will treat Section 75 in a deeper analysis.

As mentioned previously, Northern Ireland's border with the Republic of Ireland was very intentionally drawn to include Protestant/loyalist communities within the Northern Irish border, and to exclude Catholic/republican populations. This gerrymandering process gave Protestants a tenuous majority within Northern Ireland, until this decade. At the time of the Belfast Agreement, the overall population in Northern Ireland was $49 \%$ Protestant and $47 \%$ Catholic. But the civil service was dominated by Protestants at that time, with a $60-40 \%$ split between Protestants and Catholics. The Fair Employment and Treatment Order finally instituted consistent data collection on this disparity across Northern Irish public agencies (including the central government, local governments, and public authorities) and authorized "appropriate and practical" affirmative action programs to eliminate agency disparities. These included movement toward quotas in hiring and promotion, as well as analysis of the impact of workforce reduction plans or redundancies. Marketing dynamics were important to the Order's implementation, as the NICS moved to make it clear that Catholics were a welcome and important part of the workforce 
for agencies. Management was encouraged to identify "chill factors" that especially discouraged Catholic participation in the public workforce, particularly in functions like public safety and corrections.

The focus of review and action under the Fair Employment and Treatment Order was managerial; data gathering, review, and strategies were to be carried out by agency leadership. On the whole this was a successful tactic, as the Catholic/Protestant disparity was steadily reduced. By 2011, 49.1\% of the NICS was Catholic, 50.9\% Protestant (while the economically active portion of the overall population was $47 \%$ Catholic, 52\% Protestant) (NISRA 2018). So the achievement of 'community background' fairness and equity within the civil service workforce was relatively steady during this period, with some exceptions. For instance, the prison services remained unequal, with prison grades of employment displaying as nearly $85 \%$ Protestant. Here, part of the explanation was reluctance among Catholics to work in this service, dominated by the interests and needs of the British military during the Troubles. Unfortunately, prison services were not a part of the Patten Commission's focus, whose policing reforms were explicitly targeted at addressing both historical difficulties and future service needs.

The Fair Employment and Treatment Order is a fine case example of the ways that expert-led, parliamentary government programing can be reformed in short order, under the right conditions. The Patten Report's efforts addressed the broader issue of community acceptance and feasibility within its reform agenda. The tense community relations especially within Belfast and Derry would require more than just marketing and hiring consideration, to make up for the militaristic nature of policing during the Troubles. The Patten Commission specified the need for a new kind of policing, detached from the past practices; linkage and meshing with the interests of community residents; and a movement from the organizational structure, symbols, and emblems 
prominent of policing in the past. So for example, the RUC was restructured and renamed the Police Service of Northern Ireland (PSNI) with new badges, uniforms, etc., aimed at creating a neutral and inclusive police force. All of these would enhance the fairness as well as the feasibility of the resulting statewide policing organization.

Within policing services, the history was especially contentious, as several different constabulary forces had provided law enforcement until the 1960s, including the Protestant-dominated RUC police force, and the even more unrepresentative quasi-military Ulster Defence Regiment and the B Specials. But by 1969, the fragmented law enforcement units were replaced by paramilitary forces on both sides of the conflict and the deployment of the British Army in August 1969 (Barry 2019). A movement back toward peace would require the disbanding and disarmament of all paramilitary forces, and the reinstatement of a more equitable and representative police service, acceptable to Catholic-nationalists. The Patten Report recommended an overhaul in policing tactics and training. Rapid response to paramilitary activities would rarely be needed; now police response would center on community crimes like vandalism, drugs, and domestic incidents. Training would correspond to new needs, focusing less on militaristic drilling and counter-insurgency/terrorist activities and more on developing positive community relations.

The Patten Report provides an eloquent statement about the conversion in policing, necessary in Northern Ireland and elsewhere around the world. Instead of a focus on the expertise and discretion, for better or worse, among police officers, policing for the 21 st century would require ownership and buy-in from community residents. A sharing and mutuality between police and the citizenry would go further in sustaining safe communities and positive perception of police services. This was the rationale for creating a police service that mirrored the community through the affirmative action-based hiring processes of the Fair Employment and Treatment 
Order. The numbers of woman and Catholic police officers were to be enhanced, not necessarily through hiring quotas, but in equal or proportional admissions to the police academy. The best of these candidates would be hired in the end, but at the start of the training process, equal access to policing jobs would be established. But for this community orientation to take hold, it would be important to communicate the changes to police strategy. Work in the police services held a stigma for many Catholics, because of the RUC's former role in upholding British rule and often violent repression of the Catholic minority. The old police force fought against both Protestant and Catholic paramilitaries, but in general was seen as having a more solid alignment with Protestant communities, less attachment to Catholic ones. A 'new' inclusive and impartial police services would need to be developed and marketed to the public in general. "So we see our approach as restorative, not retributive - restorative of the values of liberty, the rule of law, and mutual respect, values that have sometimes been casualties of the years of violence" (Commission 1999: 4). The report reflected a solid movement to a new values base.

The Patten Commission recognized the significance of symbols and artifacts as a contentious base for political and organizational cultures (Schein 1992). Old symbols with their tensions would need to be replaced with new ones that could be considered more inclusive, or at least not exclusive of formerly conflicting sides. The RUC, considered to be a one-sided title for the police, was replaced with the more progressive Police Services of Northern Ireland. Badges and emblems for the new PSNI did not include symbols such as the crown or other linkages to the UK. But nor would the logos and images of the PSNI include any Celtic or Irish references. Police facilities around Northern Ireland would not fly the Union Jack at their fronts, instead opting for a specific flag of the PSNI. But the police services did not entirely dismiss a committed history to law enforcement; memorials to fallen police officers were retained, as they 
were emblematic of a commitment to a policing mission. The color of police uniforms was retained from the past, but the functional style was updated. A balance to the look and feel of the PSNI was maintained, generally favoring the continuation of good policing but now in a manner acceptable to and effective for the entire community.

The Patten Report was widely praised following its publication in 1999. Over the following years, loyalists and republicans found reasons to oppose some of the implementation specifics that emerged from the Report, but within the decade, the well-crafted particulars had been enmeshed in the new police force (Shearing 2010). The image and practices of the reformed police agency have become well established. Nevertheless, the PSNI would be one of the Northern Irish public functions that struggled with equity in hiring over time. Where the overall balance between Protestants and Catholics in the NICS is 51\%-49\%, the Catholic make-up of the PSNI is approximately $31 \%$, as some of the historical stigma remains regarding policing. Law enforcement is likely the most contentious discipline in Northern Ireland's civil service, so this can still be considered a relatively progressive reform since the Belfast Agreement. Successes in diversifying the civil service and establishing a relatively diverse and much more community-oriented police services are highlights in Northern Ireland's progression from its violent past. But there is still potential for advancement at the community level, as residential areas and schools are still segregated in Northern Ireland's largest urban areas. As many as 95\% of Northern Ireland schoolchildren attend a public school that matches with their either Protestant or Catholic faith identity. The focus of equality-based reforms has moved away from 'community background' in the second decade of the 21 st century, toward previously neglected concerns of the disabled, gender, LGBTQ issues, race, and ethnicity. The mechanism whereby other equality advancements have been made is worth studying in the next portion of this 
chapter. With more practice, the Section 75 screening and assessment procedures may be up to tackling the education and housing segregation issues, in time.

\section{Assessment and Evidence of Progress}

The Good Friday/Belfast Agreement was the negotiated peace settlement signed by the political leaders of the Republic of Ireland and the UK; the parliamentary act that rendered the specifics for the UK government was the Northern Ireland Act of 1998. The legislation included human rights protections, the formation of the Equality Commission of the Northern Ireland government, and 'equality mainstreaming' guidance known commonly as 'Section 75 ' of the Northern Ireland Act. Donaghy (2004) defines mainstreaming as "a strategy that aims to promote an equity perspective throughout the policymaking process, from conception to implementation to review, and all stages in between" (393). Mainstreaming efforts may be aimed at single affected groups, such as women, or as in the case of Section 75, they may affect the spectrum of inequalities. These efforts also contrast between expert-driven internal processes and more widely consultative processes. In the case of Section 75 , deliberation in the screening and assessment of policy impacts is central to the implementation of the law, and thus provides an important area to carry out potentially 'nervous' dialogues about fairness in policymaking (Donaghy 2004; Egan and Murray 2007) (Table 10.1).

\section{<COMP: Place Table 10.1 Here>}

Section 75 promotes a focus on two aspects of policy setting within all of the activities of Northern Ireland public authorities (government agencies, local governments, and other commissions and organizations). The first statutory duty under Section 75 is the promotion of equality of opportunity for nine potentially affected equality groups: those of different religious belief, political alignments, race, age, marital status, sexual orientation, gender, disability status, 
and parenting situations for those with or without dependents. Second, public authorities are required to promote good relations between affected groups (including religion, political opinion, and racial group). The Equality Commission of Northern Ireland picked up the duties to implement Section 75 in 1998. It provides an information clearinghouse of equality statistics as well as annual reporting from public authorities; offers training sessions on Section 75 and the analytic, deliberative, and consultation processes to carry out the law; and investigates complaints from citizens who feel they have been adversely affected by policies carried out by public authorities.

Section 75 adopted a holistic approach to equality protection from the outset, as the list of nine affected groups has been consistent from the writing of the legislation. Analysts were largely supportive of the recognition of all forms of inequality within the definition of affected groups, negating any elevation of especially protected identities, as well as recognizing the potential for the meshing of these group identities (Donaghy 2004). 'Community background,' as mentioned previously, tends to combine religious (Protestant/Catholic) and political (loyalist/republican) factors. As with the Fair Employment and Treatment Order, many public authorities met the new self-analytic requirements of Section 75 with enthusiasm, but early progress was inconsistent across the Northern Ireland government. The Equality Commission standardized the implementation process and reporting in 2010, through its "Guide for Public Authorities." Agency dialog and public consultation included structured screening and impact assessment procedures, based on the following questions applied to existing and new policy initiatives and applied to each of the nine equity groups in turn:

-What is the likely impact on equality of opportunity for those affected by (enacted) policy, for each of the Section 75 equality categories? 
-Are there opportunities to better promote equality of opportunity for people within the...categories?

- To what extent is the policy likely to impact on good relations between people of a different religious belief, political opinion, or racial group?

- Are there opportunities to better promote good relations between people of different religious belief, political opinion, or racial group? (Section 75 Guide, 54)

Through this systematized screening process, a given policy might be 'screened out,' meaning that it would not affect any group inequitably, or it might be 'screened in' and need some form of adjustment to maintain equitable treatment of affected groups if possible. Those policies that were screened in would be further analyzed through an impact assessment procedure, to track equality protections for the affected groups. For example, at the local government/council level, the 2016 Local Government Regulations permit any council decision or strategy could be 'called in' by $15 \%$ of councillors if they think the decision will disproportionately and negatively affect a section of the local community. The Regulations state that the following grounds must be met "(a) the section of the inhabitants of the district that would be affected by the decision; and (b) the nature and extent of the disproportionate adverse impact." This call in procedure thus offers another protective mechanism against discrimination and inequality.

While the reporting process under the "Guide's" new design requires annual review, there are no sanctions or penalties for failing to file reports. However, if an authority does file, there is a $50 \%$ rate of discussing policy accommodation focuses (Commission 2018). Mainstreaming under the revised guidance focuses on at least the following four themes, between 2015 and 2018:

-Disabilities access. The Department of Education has enhanced its focus to serve children with autism and spectrum disorders through increased screening and coordinated training with the Department of Health. Autism and Asperger's syndrome have been identified as rapidly growing health conditions, and treatment of the issue within primary schools is the next step after an overall Autism Strategy within health services. One of the main workforce development programs, "Steps 2 Success" or S2S, has recruited consultants to review disabilities access to both its web portal and to the specific program initiatives. For example, since one of the 
protected groups under Section 75 is people with dependents, the inclusion of child care within the training program has been funded. In another use of affected consultants, elderly volunteers have been involved in testing the City of Belfast's infrastructure development plan.

-Awareness education: The Health and Education Departments are expanding educational programs and modules around a wide range of affected groups and issues. In 2017 alone, designated panels and sessions were formed around issues for new immigrants to Northern Ireland, LGBTQ educational focuses, autism awareness, single parenting, and mental health disparities. Specific groups have had their issues highlighted by Northern Ireland and City of Belfast governments including Deaf Awareness Week, Belfast Pride Day, Transgender Day of Remembrance, the Women in Business NI Leadership Conference, and DisabledGo training days.

-Expanded culture and arts access: The City of Belfast has expanded its criteria for arts grants and programing to include diversity focuses, including support for the Outburst Queer Arts Festival, Belfast Pride, the Belfast Children's Festival, the Bounce! Disabilities Arts Festival, and Exhibitions at the Chinese Welfare Association and the Northern Ireland Community of Refugees and Asylum Seekers.

- Hate crimes and anti-bullying: The PSNI and Department of Education collaborate on educational programing and increased enforcement of hate crimes, as protections for new immigrant populations, the disabled, and LGBTQ youths. In November 2017, over 800 organizations participated with the Department of Education in 'Anti-bullying Week,' with the theme, 'All equal, All different, All together.' PSNI's policy changes have especially emphasized the protection of victims of hate crimes over conviction of the perpetrators.

The Section 75 reports database inventories the impacts of policy changes across the nine affected groups, but the collaboration across public authorities is striking. While the focus specifies more impacts within peoples with disabilities, immigrants, and LGBTQ communities within the past three years, there is an interesting collaboration on the long-standing 'community background' issue. For centuries, Protestant communities have celebrated victories such as William of Orange's triumph with parades and bonfires on the anniversary day. July 11 and August 8 are the major bonfire days across Belfast, and have long been flash points for violence. But the PSNI, City of Belfast, and other agencies have pursued an effort to convert the bonfire commemorations to more inclusive celebrations, better-managed sites (keeping fires under better control), and even substitution of the bonfires for other activities. A positive interpretation could 
be that Northern Ireland is reaching the point where it can get beyond the violent earlier conflict underlying the Troubles, and move toward larger transformations with regard to broader equality.

\section{Conclusion}

This study of predominantly faith- and politics-based inequity in Northern Ireland expands on Gooden's work in predictable or consistent ways, as well as in some varied and unexpected ones.

To the first point, inequity and the historical abuse of power is ubiquitous in our world. But a sort of awakening comes to many states and their communities; government deliberation and action may develop appropriate legal responses to the institutional inequity that emerged. Along the way, the tension in having the discussion about difference and inequity is difficult to initiate and daunting to pursue, at the outset. But it can be transforming for our vision of a fair and just public service contribution.

What were the differences between the racial inequity case developed in Gooden's initial study, and the political and faith-based divide in Northern Ireland? The reconciliation between the depths of the inequity, involving slavery in the United States and colonialism in Ireland/Northern Ireland, ended many years ago in both places (in 1865 and 1922, respectively), but the unrest, deep distrust, and constant tensions between groups was especially violent and concentrated in Northern Ireland (nicely captured in the title of one of the many books about Northern Ireland, Jonathan Powell's Great Hatred, Little Room), which led to a very specific second reconciliation in 1998 with the Good Friday Agreement. This is meant by no means to dismiss any of the violence in the engagement of Reconstruction and civil rights in the United States, only to highlight the concentration of conflict in the two Northern Irish cities of Belfast and Derry, especially. Affirmative action is a policy used to address inequity in both places, but is much 
more contentious in the United States than in Northern Ireland. It appears that the latter state was far more willing to accept the need for the policy, following 1998.

In Northern Ireland, the dialogue about religious and political contrasts starts differently and maybe more contentiously. The 'community background' differences are unseen until the verbal cues highlight the difference. So the initial dialogue can be where the contentiousness starts. It appears that the resolution, since 1998, has been a smoother discussion. This may arise from a shared sense on both 'sides' that the violence that can erupt does need to be quelled if possible. And more to the point that public policies and institutional changes and initiatives are needed to address some of the underlying causes of that conflict, not least discrimination, unequal treatment, and experiencing public services as non-neutral and partial towards one side of the community. So this chapter has highlighted that 'nervousness' might have a cultural difference, within the history, intensity, and concentration of the divisions between peoples, including the 'long memory' of the legacy of unstable, contested, and often violent relations between the two communities.

The policy differences that emerge in the United States and Northern Ireland are interesting. Gooden lays out very effectively how government-endorsed housing discrimination segregated American society, and the "saturation" led to further unfairness. Predominantly African American communities suffer from lagging economic development because of discriminatory support from the banking industry; and thus property values in African American communities are lower. Since the dominant tax source for municipalities in the United States is the local community's property tax, there are consequently less financial resources in these communities. Local services suffer-with the most dominant local service in American communities being their school system. And thus opportunity for African Americans, within this saturated system, is 
societally constrained. Some cities and states in the United States have implemented separate structures to enhance equity in funding for school systems, but these have a long way to go. Funding is not the issue in Northern Irish communities, but the segregation is. As mentioned above, over $95 \%$ of Northern Irish children study in schools with other children of their shared faith. Interestingly, Catholic children now have higher attainment to college and university studies than Protestant children; so the inequity has almost reversed on this dimension, but at the expense of shared schooling as enhancing reconciliation and creating positive community relations. All that said — cultural dispositions lead to a different form of nervousness, and at the margins, different ways to initiate and proceed through the conversation to overcome it.

Northern Ireland has made progress since its 1998 Peace Agreement on addressing discrimination and inequality including the creation of a more peaceful society and, at first, a more consensual governance system. It has an impressive policy architecture for monitoring and delivering equality in public services and government decision-making, yet more needs to be done, not least in tackling its still segregated primary and secondary education system and encouraging more Catholics to join the police and prison services. But there are three additional 'nervous areas of government' or sources of nervousness with which we conclude. These relate to important issues to do with the past, the present, and the future of and for Northern Ireland. It is perhaps a testament to the success of the post-1998 political and policy system in Northern Ireland in dealing with and addressing inequalities between the two communities, that one of the major political issues still unresolved in Northern Ireland is the legacy of the past conflict. How to deal with the past was not addressed in the 1998 Agreement but has risen up the political agenda in recent years as victims and survivors of paramilitary and state violence seek truth, justice, compensation, or some combination of all three. While the UK government has 
suggested a way forward (NIO 2018), and these proposals are currently out for consultation, the issue and the proposal has caused deep divisions within Northern Ireland between victims and survivors, between the Northern Irish political parties, and between the British and Irish governments. But everyone agrees that a way to deal with the past is absolutely vital if Northern Ireland is to move from a 'peace process' and conflict management to reconciliation and conflict transformation.

The issue relating to the present is one that is a great threat to the peace process and the post1998 political settlement. That issue is Brexit, the decision by referendum in 2016 that the UK leaves the European Union. The fact that Northern Ireland voted to remain and that those parties pushing for Brexit are mostly unionist ones (DUP, UUP, TUV) has added an additional set of tensions to the already fragile relations between unionist and nationalist political parties and communities. Not least is the fact that Brexit has been used as an opportunity by the largest nationalist party, Sinn Fein, to call for a border poll for a United Ireland. This has predictably caused concern and anxiety among large sections of the unionist population and political parties who are nervous about their status in any future reunified Ireland when they would be a minority on the island, and related to the latter that the demographic trends within Northern Ireland are such that there will be a Catholic majority within the next decade. An example of the changed status for the once dominant group is that since the 2018 Assembly election, unionist parties are, for the first time in Northern Ireland's history, not long the majority in the Assembly. Brexit has not only been seized opportunistically to call for a border poll, but has at one and the same time also raised the prospect or specter of return to a 'hard border' in Ireland. Not least among those pushing for a 'hard Brexit' i.e. cutting all links with the European Union, an impact of a hard Brexit might be the return of physical infrastructure along the border. This would undermine the 
progress since 1998 of there being no guards or border posts along the border which has both symbolically and empirically reduced tensions and normalized relations between communities in the two jurisdictions and lessened tensions between communities within Northern Ireland, especially those in border counties. As we write Brexit has still not been resolved with the UK government and Parliament completely divided and unable to come up with and deliver a Brexit deal. These divisions mirror the deep divisions Brexit has exposed within UK society, and it has done nothing but increases tensions within Northern Ireland.

While also a current issue, climate breakdown and ecological degradation will dominate politics and policy for decades to come, and as such is as much a future issue to consider as it is a current pressing one. Whether as a result of the remarkable school strike for climate movement of school children led by the Swedish teenager Greta Thunberg, the more non-violent direct action of the Extinction Rebellion movement, the remarkable success of David Attenborough's Blue Planet program and others to popularize the plastic pollution crisis in our oceans and his prominence in public debates on climate breakdown, it does seem that a 'tipping point' has been reached on our climate and ecological crises. So, while like other societies Northern Ireland will have to face these and find responses (and here given its unique status one could say it should benefit from the fact that both the UK and Irish Parliaments have recently declared 'Climate and Ecological Emergencies'), Northern Ireland is burdened not only by dealing with these global and existential threats, but has to look backward as well as forward as it were to deal with the legacy of the past; the current chaos caused by Brexit; and the even greater chaos and devastation that climate and ecological breakdown heralds unless radical and transformative changes are made quickly and in all areas of life (from our food system, the energy system, transportation options, building systems, and others). But perhaps oddly Northern Ireland and its uneven peace process 
have something to offer in responding to climate and ecological breakdown. This has to do with the often overlooked fact that the transformations required to adequately deal with the climate emergency will produce winners and losers. And therefore conflict management and transformation strategies should be seen as central elements of any transition from 'actually existing unsustainability' (Barry 2012), for example how to create processes for those who will lose from the transition to a climate resilient and low carbon economy (such as workers, communities, and companies involved in the fossil fuel energy sector). And here, on this issue of finding compromise, negotiating a fair agreement on a way out of the climate and ecological crisis, Northern Ireland might have something to offer, such that its name begins to be associated with something other than its past history of violence and division.

\section{Notes on Contributor}

Brendan Burke is an associate professor at Suffolk University, in Boston, Massachusetts. His research and teaching interests include organizational theory, administrative reform, executive leadership, and comparative public administration. He has published in the American Review of Public Administration, Public Administration Review, Publius: The Journal of Federalism, State and Local Government Review, and other journals. Prior to his academic career, he served local government managers in North Carolina and Virginia; he currently holds advisory board positions with the Massachusetts Department of Mental Health.

John Barry is Professor of Green Political Economy in the School of History, Anthropology, Philosophy and Politics at Queen's University Belfast. His main research interests include the ethics of sustainability/sustainable development, green moral and political theory, green political economy, civic republicanism and green politics, Irish/Northern Irish politics, and sustainable energy politics and policy. His extensive publications include the books Environment and Social 
Theory (Routledge Taylor \& Francis) and The Politics of Actually Existing Unsustainability:

Human Flourishing in a Climate-changed, Carbon-constrained World (Oxford University

Press). He is civically active in organizations ranging from school board to Green Party in Northern Ireland.

Figure 10.1 Catholics in Northern Ireland Civil Service, 1920-2018.

Missing Civil Service data from 1930s to 1980s. Sources: The 1981 Northern Ireland Census Report, Religion Report; Northern Ireland Statistics and Research Agency; Northern Ireland Equality Commission.

Table 10.1 Equality Reform Steps and Actions in Northern Ireland, 1998-Current

\begin{tabular}{|c|c|c|c|c|}
\hline Action & Focus & Participants & Mechanisms & Assessment \\
\hline $\begin{array}{l}\text { Good Friday } \\
\text { Agreement } \\
\text { (1998) }\end{array}$ & $\begin{array}{l}\text { Initiation of } \\
\text { peace between } \\
\text { Northern } \\
\text { Ireland } \\
\text { factions }\end{array}$ & $\begin{array}{l}\text { UK and Irish } \\
\text { governments; } \\
\text { Northern Ireland } \\
\text { Political Parties }\end{array}$ & $\begin{array}{l}\text { Acceptance of } \\
\text { national identities } \\
\text { and "Power } \\
\text { Sharing" of } \\
\text { political leadership }\end{array}$ & $\begin{array}{l}\text { Cornerstone of } \\
\text { Northern Ireland } \\
\text { governance since } \\
\text { its signing; but } \\
\text { Power Sharing” } \\
\text { collapsed in } 2017\end{array}$ \\
\hline $\begin{array}{l}\text { Fair } \\
\text { Employment } \\
\text { and } \\
\text { Treatment } \\
\text { Order (1998) }\end{array}$ & $\begin{array}{l}\text { Integration of } \\
\text { Catholics into } \\
\text { the Northern } \\
\text { Ireland Civil } \\
\text { Service } \\
\text { (NICS) }\end{array}$ & $\begin{array}{l}\text { UK Parliament } \\
\text { and NICS }\end{array}$ & $\begin{array}{l}\text { 'Affirmative } \\
\text { Action' in NICS } \\
\text { hiring; data } \\
\text { collection tracking } \\
\text { disparities }\end{array}$ & $\begin{array}{l}\text { Since } 1998, \text { the } \\
60-40 \text { split } \\
\text { between } \\
\text { Protestants and } \\
\text { Catholics in NICS } \\
\text { has been virtually } \\
\text { equalized }\end{array}$ \\
\hline
\end{tabular}




\begin{tabular}{|c|c|c|c|c|}
\hline $\begin{array}{l}\text { Patten Report } \\
\text { (1999) }\end{array}$ & $\begin{array}{l}\text { Policing } \\
\text { reform, from } \\
\text { fighting } \\
\text { terrorism and } \\
\text { armed conflict } \\
\text { to community } \\
\text { policing }\end{array}$ & $\begin{array}{l}\text { Public safety } \\
\text { leadership and } \\
\text { experts from } \\
\text { around the } \\
\text { world, led by Sir } \\
\text { Christopher } \\
\text { Patten }\end{array}$ & $\begin{array}{l}\text { Careful definition } \\
\text { of community } \\
\text { policing; enhanced } \\
\text { recruitment of } \\
\text { women and } \\
\text { Catholics into } \\
\text { policing; formation } \\
\text { of the Police } \\
\text { Services of } \\
\text { Northern Ireland }\end{array}$ & $\begin{array}{l}\text { "Rebranding" of } \\
\text { PSNI and } \\
\text { retraining focus is } \\
\text { a worldwide } \\
\text { model; Catholic } \\
\text { representation in } \\
\text { PSNI and } \\
\text { corrections still } \\
\text { lags at } 30 \% \text { of } \\
\text { Catholic } \\
\text { population }\end{array}$ \\
\hline $\begin{array}{l}\text { Section } 75 \text { of } \\
\text { Northern } \\
\text { Ireland Act } \\
\text { of } 1998\end{array}$ & $\begin{array}{l}\text { Analysis and } \\
\text { resolution of } \\
\text { 'community } \\
\text { background' } \\
\text { and other } \\
\text { inequities in } \\
\text { Northern Irish } \\
\text { society }\end{array}$ & $\begin{array}{l}\text { UK Parliament; } \\
\text { newly formed } \\
\text { Equality } \\
\text { Commission of } \\
\text { Northern } \\
\text { Ireland; all } \\
\text { statewide and } \\
\text { local } \\
\text { government } \\
\text { organizations }\end{array}$ & $\begin{array}{l}\text { Standardized } \\
\text { screening and } \\
\text { implementation } \\
\text { assessment of } \\
\text { potential } \\
\text { inequitable } \\
\text { government } \\
\text { decisions }\end{array}$ & $\begin{array}{l}\text { Annual reporting } \\
\text { through the } \\
\text { Commission } \\
\text { offers numerous } \\
\text { "best cases" of } \\
\text { inequity reduction } \\
\text { for disabled, } \\
\text { LGBTQ, ethnic, } \\
\text { gender, and other } \\
\text { groups }\end{array}$ \\
\hline
\end{tabular}

\section{References}

Barry, J. (2019). The outbreak and development of the 'troubles'. Belfast: Island Publications. 
Bew, P. (2010). Ireland. The politics of enmity. Oxford: Oxford University Press.

Bolman, L., and Deal, T. (2013). Reframing organizations: Artistry, choice and leadership. Fifth Edition. San Francisco, CA: Jossey Bass.

Brennan, S. (2017). Ulster's uncertain menders?: The challenge of reintegration and reconciliation for Ulster Loyalists in a post-ceasefire society, unpublished $\mathrm{PhD}$ thesis. Belfast: Queen's University Belfast.

Buckland, P. (1979). The factory of grievances: Devolved government in Northern Ireland, 1921-1939. Dublin: Gill Macmillan.

Burns, A. (2018). The milkman. London: Faber \& Faber.

Donaghy, T.B. (2004). Applications of mainstreaming in Australia and Northern Ireland. International Political Science Review 25(4), 393-410.

Egan, S., and Murray, R. (2007). A charter of rights for the Island of Ireland: An unknown quantity on the Good Friday/Belfast Agreement. International and Comparative Law Quarterly 56, 797-836.

Equality Commission for Northern Ireland. (2010). Section 75 of the Northern Ireland Act of 1998: A guide for public authorities. Belfast: Equality Commission.

Equality Commission of Northern Ireland. (2018). Section 75 statutory equality and good relations duties acting on the evidence of public authority practices. Belfast: Equality Commission.

Gooden, S. (2014). Race and social inequity: A nervous area of government. Armonk, NY: ME Sharpe.

Hayes, B., and McAllister, I. (2001). Who voted for peace?: Public support for the 1998 Northern Ireland Agreement. Irish Political Studies 16(1), 73-93.

Independent Commission on Policing in Northern Ireland. (1999). A new beginning: Policing in Northern Ireland. London: H.M.S.O.

Irish Times (Editorial). (2010, May). Civil service in North short on Catholics. Irish Times, 10. Kane, A. (2019). Half-a-century on, we've still to learn lessons of Terrence O’Neill. Belfast Telegraph (https://www.belfasttelegraph.co.uk/opinion/columnists/halfacentury-on-wevestill-to-learn-lessons-of-terence-oneill-30905355.html, accessed May 26, 2019)

Long, S. (2018). The politics of misrecognition: An insider analysis of political loyalism and its 'place in the peace', unpublished $\mathrm{PhD}$ thesis. Belfast: Queen's University Belfast. 
McGarry, F. (2019). Reframing Ireland's revolution. In McGarry, F., and Delaney, E. (eds). The Irish revolution 1919-21: A global history. (8-12). Dublin: History Publications Ltd.

McMahon, S. (1996). A short history of Ireland. Chester Springs, PA: Dufour Editions.

Northern Ireland Office. (2018). Addressing the legacy of Northern Ireland's past

(https://www.gov.uk/government/consultations/addressing-the-legacy-of-northern-irelandspast, accessed May 31, 2019)

Northern Ireland Statistics and Research Agency. (2018). Equality statistics for the Northern Ireland Civil Service. Belfast, NI: NISRA.

Patterson, H. (2007). Ireland since 1939: The persistence of conflict. London: Penguin Books.

Schein, E. (1992). Organizational culture and leadership. Second Edition. San Francisco, CA: Jossey-Bass.

Shearing, C. (2010). The curious case of the Patten Report. In Doyle, J. (ed). Policing the narrow ground: Lessons from the transformation of policing in Northern Ireland. (27-38). Dublin:

Royal Irish Academy. 